\title{
Brusella Epididimoorşitli 7 Vakanın Değerlendirmesi
}

\section{Evaluation of Seven Cases with Brucella Epididymo- Orchitis}

Merve Sefa Sayar ${ }^{1}$,

Gönül Çiçek Şentürk²,

Halime Lülleci²,

Fatma Aybala Altay²,

Aslı Haykır Solay ${ }^{2}$

${ }^{1} T C$ SBÜ Van Eğitim ve Araştırma

Hastanesi Enfeksiyon Hastalıkları ve Klinik Mikrobiyoloji

${ }^{2} T C$ SBÜ Yıldırım Beyazıt Eğitim ve

Araştırma Hastanesi Enfeksiyon Hastalıkları ve Klinik Mikrobiyoloji

Gelis Tarihi/Received: 31 Ocak 2017

Kabul Tarihi/Accepted: 30 Ey/ül 2017

Yazışma Adresi: Merve Sefa Sayar,

TC SBÜ Van Eğitim ve Araştırma Hastanesi Enfeksiyon Hastalıkları ve Klinik Mikrobiyolojii, Van, Türkiye

e-posta: drmervesefasayar@yahoo.com

ORCID

Merve Sefa Sayar

https://orcid.org/0000-0002-0436-4122

\begin{abstract}
Öz
Bruselloz ülkemizde sık görülen zoonotik bir hastalıktır. Sistemik bir enfeksiyon olan burselloz; çeşitli klinik tutulumlarla karşımıza çıkabilmektedir. Genitorüriner tutulum ise \% 4-20 arasında değişen oranlarda görülmektedir. Değerlendirmiş olduğumuz yedi epididimoorşit vakasına anamnez, fizik muayene ve ultrason ile tanı konulmuştur. Hastalarımızın hepsi taşra hastası olup; anamnezlerinde enfekte süt ve süt ürünleri yeme ile hayvanlarda düşük yapma öyküsü bulunmaktadır. Yedi vakanın sadece ikisine coombslu tüp aglütinasyon testi ile tanı konulmuştur; beş vakada standart tüp aglütinasyon testi tanıda yeterli olmuştur. Üç hastada kan kültürü pozitifliği saptanmıştır. Hastalar brusella tedavisini altı hafta alarak iyileşmiştir. Hastaların tamamına kombine tedavi uygulanmıştır. Hastalarımızın hiçbirinde tedavi yetersizliği saptanmamıștır. Yazımızda; epididimoorşit tanısı alan hastaların öykülerinde brusellozun göz önünde tutulmasını sağlamak amaçlanmıştır. epididimoorşit tanısı alan hastaların öykülerinde brusellozunda göz önünde tutulmasını sağlamaktır.
\end{abstract}

Anahtar Kelimeler: Bruselloz, epididimoorşit, tedavi

\section{Abstract}

Brucellosis is one of the most frequent zoonotic diseases in our country. Brucellosis, a systemic infection, can arise with various clinical involvements. Genitourinary involvement is seen at varying rates between $4-20 \%$. Seven examined epididymo-orchitis cases were diagnosed through anamnesis, physical examination and ultrasonography. All of our patients are provincials, in their anamnesis, there are histories regarding eating infected milk and dairy products and miscarriages in animals. Only in two of seven cases, diagnosis was made through coombs tube agglutination; in the other five of seven cases, standard tube agglutination test was sufficient for diagnosis. Blood culture positiveness was determined in three patients. Patients were healed by taking brucella treatment for six weeks. Combined modality therapy was administered to all patients. Treatment deficiency was not determined in any patients. In this article, we aim to provide taking into consideration also brucellosis in histories of patients having epididymo-orchitis treatment.

Keywords: Brucellosis, epididymo-orchitis, treatment

\section{GíRiş}

Ondülan ateş, malta ateşi, gastrik remitant ateş ve akdeniz ateşi olarak da adlandırılan bruselloz; zoonotik bir enfeksiyon hastalığıdır. Hastalık koyun, keçi, sığır gibi hayvanların etleri, süt ve idrar gibi vücut sıvıları, enfekte sütleri ile hazırlanan süt ürünleri, enfekte hayvana direk temas ya da enfekte aerosollerin inhalasyonu aracılığı ile insanlara bulaşır (1). Sanayileşmiş ülkelerde sıklıkla mesleki temas sonucu gelişen hastalık; gelişmekte olan ülkelerde ciddi ekonomik kayba neden olan önemli bir halk sağlığı problemidir. Türkiye'de sıklık sırasına göre Güneydoğu Anadolu, Doğu Anadolu ve İç Anadolu bölgelerinde görülmektedir (2). Bruselloz farklı klinik tablolarla tüm sistemleri etkileyen multisistemik bir hastalıktır. Bruselloza bağlı epididimoorşit vakaları \%220 'sini oluşturmaktadır (3). Brusellar epididimoorşit (BEO) olgularını değerlendirdiğimiz yazımızda; brusellozun endemik olduğu bölgelerde epididimoorşit vakalarında ayırıcı tanılar arasında BEO'inde akılda tutulmasını sağlanmak amaçlanmıştır.

\section{OLGU \\ Olgu 1:}

Kırk dokuz yaşında erkek hasta, bir buçuk aydır yaygın vücut ağrısı, halsizlik, gece terlemesi şikayetleri mevcut; son birkaç gündür şikayetlerinde artma, skrotumda şişlik ve ağrı şikayetlerinin de

Atıf yapmak için: Sayar MS, Şentürk GÇ, Lülleci H, Altay FA, Solay $\mathrm{AH}$. Brusella Epididimoorşitli 7 Vakanın Değerlendirmesi. Selcuk Med J 2019;35(4): 259-263

Açıklama: Yazarların hiçbiri, bu makalede bahsedilen herhangi bir ürün, Aygut veya ilac ile ilgili maddi Gikar iliskisine sahip değildir. Arastırma birincil verilerine tam erişim izni vermek ve derginin talep ettiği takdirde verileri incelemesine izin vermeyi kabul etmektedirler. 
eklenmesi üzerine epididimoorşit tanısı ile kliniğimize yatışı yapıldı. Hastanın ailesinde brusella öyküsü bulunuyordu. Fizik muayenesinde skrotum şiş ve kızarıktı; hastanın diğer sistem muayeneleri olağandı. Laboratuvar bulgularında Beyaz Küre (BK): $7800 \mu \mathrm{L}$, Trombosit: $252000 \mu \mathrm{L}$, Sedimantasyon (ESR): 55 $\mathrm{mm} / \mathrm{saa}, \mathrm{C}-$ reaktif protein (CRP): 41,1 mg/l, AST: 68 U/I, ALT: $79 \mathrm{U} / \mathrm{l}$, standart tüp aglütinasyon testi (STA): 1/160 titrede pozitif idi. Hastaya doksisiklin 2x100 mg ve rifampisin 1x600 mg başlandı. 6 hafta süreyle tedavi verildi. Hastanın kontrollerinde şikayeti olmadı.

\section{Olgu 2}

Bir ay önce kırsal bölgeye ziyaretinde taze peynir yeme öyküsü olan 52 yaşında erkek hastanın 15 gündür ateş, yaygın eklem ağrısı ve iştahsızlık şikayetleri bulunmaktaymış. Hasta skrotumda şişlik ve kızarıklık şikayeti ile polikliniğe başvurdu ve epidimoorşit tanısı ile servise yatışı yapıldı. Laboratuvar bulgularında BK: $7300 \mu \mathrm{L}$, Trombosit: $245000 \mu \mathrm{L}$, ESR: $30 \mathrm{~mm} / \mathrm{saat}$, CRP: 16,1 mg/l, AST: $32 \mathrm{U} / \mathrm{I}, \mathrm{ALT}: 55 \mathrm{U} / \mathrm{I}, \mathrm{STA}: 1 / 640$ titrede pozitif saptandı. Kan kültürlerinden 6 adet Brusella spp. üremesi oldu. Hastaya BEO tanısı konularak doksisiklin 2x100 mg ve rifampisin 1x600 mg başlandı. Tedavisi 6 haftaya tamamlandı. Hastanın kontrollerinde şikayeti olmadı.

\section{Olgu 3}

Otuz iki yaşında erkek hastaya 1 haftadır ateş ve sağ skrotumda şişlik şikayeti olması nedeni ile üroloji polikliniğinde epididimoorşit tanısı konularak; gentamisin ve siprofloksasin tedavisi başlanmış. Şikayetlerinde gerileme olmayan hasta enfeksiyon hastalıkları polikliniğine yönlendirilmiş ve hasta ileri tetkik amaçlı enfeksiyon hastalıkları kliniğine yatırıldı. Hasta öyküsünde; geçimini hayvancılık yaparak sağladığını ve son dönemde bazı hayvanlarının düşük yaptığını belirtti. Fizik muayenesinde ateş: $38,7^{\circ} \mathrm{C}$, sağ skrotumda şişlik, kızarıklık ve ısı artışı mevcuttu. Laboratuvar bulgularında BK: $11500 \mu \mathrm{L}$, Trombosit: $172000 \mu \mathrm{L}$, ESR: $65 \mathrm{~mm} / \mathrm{saat}$, CRP: 186 mg/l, AST: 70 U/I, ALT: 34 U/I, STA: 1/320 titrede pozitif idi. Kan kültürlerinden Brusella spp. üremesi oldu. Hastaya doksisiklin $2 \times 100 \mathrm{mg}$ ve rifampisin $1 \times 600 \mathrm{mg}$ başlandı. 4 gün tedaviyi almasına rağmen şikayetlerinde gerileme olmaması; ayrıca bulantı ve kusma şikayetlerinin olması nedeni ile tedavisi doksisiklin 2x100 mg ve streptomisin 1×1 g olarak değiştirildi. Tedavi değişikliğinin 2. gününde lezyonda gerileme oldu ve hastanın ateşi düştü. 14 gün streptomisin $1 \times 1 \mathrm{~g}$ ve doksisiklin 2x100 mg alan hastanın tedavisi doksisiklin $2 \times 100 \mathrm{mg}$ ve rifampisin $1 \times 600 \mathrm{mg}$ olarak 6 haftaya tamamlandı. Kontrollerinde şikâyeti olmadı.

\section{Olgu 4}

Yirmi beş yaşında erkek hasta bir hafta önce başlayan ateş yüksekliği şikayetine; sağ skrotumda şişlik ve bel ağrısı eklenmesi üzerine polikliniğimize başvurdu. Hasta enfeksiyon servisine epididimoorşit tanısı ile yatırıldı. Fizik muayenesinde sağ testiste şişlik mevcut olan hastanın diğer sistem muayeneleri olağandı. Laboratuvar bulgularında BK: $17500 \mu \mathrm{L}$, Trombosit: $213000 \mu \mathrm{L}, \mathrm{CRP}: 127 \mathrm{mg} / \mathrm{l}$, ESR: $35 \mathrm{~mm} /$ saat, AST:53 U/l, ALT:93 U/I, STA: 1/80 titrede pozitif, coombslu: $1 / 160$ pozitif idi. Hastaya doksisiklin 2x100 $\mathrm{mg}$ ve rifampisin 1x600 mg başlandı. Tedavisinin 3 . gününde ateşi düştü. Hastanın tedavisi 6 haftaya tamamlandı. Kontrollerinde şikayeti olmadı.

\section{Olgu 5}

Kırk üç yaşında erkek hastanın; iki haftadır skrotal bölgede şişlik, ateş, üşüme ve titreme şikayetleri bulunmaktaymış. Hasta bu şikayetlerle üroloji polikliniğine başvurmuş; ancak verilen ampirik tedaviye rağmen şikayetlerinin devamı üzerine enfeksiyon polikliniğine yönlendirilmiş. Enfeksiyon hastalıkları tarafından poliklinikte değerlendirilen hasta; çocuğuna daha önce brusella tanısı konmuş olması, hayvancılıkla uğraşması ve hayvanlarında düşük olması nedenleri ile brusella araştırılmak üzere kliniğe yatışı yapıldı. Fizik muayenesinde sol testiste şişlik ve hiperemi mevcut olan hastanın sistem muayeneleri normaldi. Laboratuvar bulgularında BK: $7160 \mu \mathrm{L}$, Trombosit: $238000 \mu \mathrm{L}, \mathrm{CRP}: 1.94$ mg/l, ESR: $16 \mathrm{~mm} / \mathrm{saat}, \mathrm{AST}: 20 \mathrm{U} / \mathrm{l}, \mathrm{ALT}: 16 \mathrm{U} / \mathrm{l}, \mathrm{STA}$ : Negatif, coombslu: 1/160 pozitif saptandı. Kan kültüründe Brucella spp. üremesi olan hastaya doksisiklin 2x100 $\mathrm{mg}$ ve rifampisin $1 \times 600 \mathrm{mg}$ başlandı. Tedavisi 6 haftaya tamamlanan hastanın kontrollerinde şikayeti olmadı.

\section{Olgu 6}

Otuz üç yaşında erkek hastanın 1 aydır halsizlik, eklem ağrısı ve yaklaşık $7 \mathrm{~kg}$ kaybı olmuş. Sağ skrotal bölgede ağrı ve şişlik şikayeti de eklenen hasta polikliniğimize başvurması üzerine; araştırılmak üzere servise yatırıldı. Hastanın hayvanlarında düşük ve taze peynir yeme öyküsü bulunmaktaydı. Fizik muayenesinde sağ testiste ödem, hassasiyet ve şişlik dışında patoloji bulunmadı. Laboratuvar bulgularında BK: $11890 \mu \mathrm{L}$, Trombosit: $149000 \mu \mathrm{L}, \mathrm{CRP}: 17,9 \mathrm{mg} / \mathrm{l}$, ESR: 32 mm/saat, AST:25 U/I, ALT: 25 U/I, STA: 1/640 pozitif idi. Hastaya doksisiklin 2x100mg ve rifampisin 1x600 mg başlandı. Tedavisi 6 haftaya tamamlanan hastanın takibinde şikayeti olmadı. 


\section{Olgu 7}

Bir haftadır ateş, halsizlik ve yorgunluk şikayeti olan kırk üç yaşında erkek hastaya aile hekimi tarafından üst solunum yolu enfeksiyonu tanısı konulup ampirik antibiyotik tedavisi başlanmış. Şikayetlerinde gerileme olmayan ve 1 hafta sonra sağ testiste ağrı ve şişlik başlayan hasta üroloji polikliniğine başvurmuş. Hastaya yapılan skrotal USG'de sağ testisde epididimoorşit saptanması üzerine; siprofloksasin başlanarak enfeksiyon polikliniğine yönlendirilmiş. Enfeksiyon polikliniğinde değerlendirilen hasta; anamnezinde üç hafta önce taze peynir yediğini belirtti. Laboratuvar tetkiklerinde BK: $5800 \mu \mathrm{L}$, Trombosit: $200000 \mu \mathrm{L}$, CRP: 14,8 mg/l, ESR: $13 \mathrm{~mm} / \mathrm{saat}, \mathrm{AST}: 34 \mathrm{U} / \mathrm{l}, \mathrm{ALT}$ : $41 \mathrm{U} / \mathrm{l}$ ve STA: $1 / 1280$ olarak saptandı. BEO tanısı konan hastanın mevcut antibiyotik tedavisi kesilerek doksisiklin 2x100 mg ve rifampisin 1x600 mg tedavisi başlandı. Tedavi başlangıcından yaklaşık 1 hafta sonra hastanın skrotal şikayetleri geriledi. Hasta tedavisini 6 haftaya tamamladı ve takibinde şikayeti olmadı.

\section{TARTIŞMA}

Ülkemizde endemik olan brusellozun en sık fokal tutulumu lokomotor sistemdedir; fakat değişen oranlarda diğer sistemlerde de tutulum yaptığı görülmüştür (4). Vakalarımızda özellikle belirttiğimiz genitoüriner sistem komplikasyonu olan epididimoorşitin görülme sıklığı; çeşitli serilerde yaklaşık \% 2-20 arasında değişen oranlarda bildirilmiştir (3). Demiroğlu et al. 151 hastalık Brusella serisinde; 8 hastada $(\% 5,3)$ genitoüriner sistem tutulumu olduğu ve bunlarında 5 'inin epididimoorşit tanısı aldığı belirtilmiştir (5). İran'da yapılan bir diğer bruselloz serisinde ise; brusellar epididimoorşit oranı \%6,7 olarak saptanmıştır (6).

Epididim spermin depolandığı, membranının olgunlaştığı ve spermlerin hareket yeteneği kazandığı yer olarak bilinmektedir. Bu bölgenin herhangi bir inflamasyonu neticesinde sperm sayısında azalma, hareketlilikte bozulma veya spermlerde disfonksiyon gelişebilmektedir. Epididimit başarıyla tedavi edilirken sekel oluşumunun fertilite üzerine potansiyel etkisi ise belirsizdir (7). Testiküler tutulum sonrasında brusella etkeni testislerde fokal nekroza ve granülomatöz enfeksiyon gelişimine sebep olmaktadır (8). Brusellozun genitoüriner tutulum yapması; seksüel yayılım olasılığını da artırmaktadır. BEO tanısı koymadaki akılcı olmayan yaklaşımlar abse oluşumu, infarkt, süpüratif nekroz, spermatojenik fonksiyon yetersizliği, infertilite ve olguların önemli bir kısmında olduğu gibi testis kaybına kadar götüren ciddi komplikasyonlara sebep olmaktadır (9).

Hayvanlar insan brusellozunun ana kaynağıdır. Bulaşın veterinerler, mezbaha çalışanları, hayvancılık gibi direk mesleki temasla olabileceği gibi pastörize edilmemiş süt ve süt ürünlerinin tüketimi ile de bulaş olmaktadır (10). Coşkun et al. retrospektif bruselloz çalışmasında 190 erişkin erkek hastada 10 epididimoorşit vakası $(\% 5,2)$ saptanmış ve epididimoorşit vakalarının 5'i kırsal bölgede yaşarken, 6'sı pastörize edilmemiş süt ürünleri kullanmaktaydı ve bu 10 vakanın 4'ünde ise mesleki maruziyet bulunmaktaydı (11). 1028 brusella vakasının irdelendiği bir başka çalışmada ise; çalışmaya dahil edilen vakaların \% 42,3'ünün hayvancılıkla uğraştığı saptanmıştır (12). Vaka serimizdeki hastaların ikisi çiftçilik ile geçimini sağlarken, üç hastamızın taze peynir yeme öyküsü ve dört hastamızın da hayvanlarında düşük ve üç kişinin düşüğe çıplak elle müdahalesi söz konusuydu.

BEO sadece genital tutulumun olmadığı; birçok sistemik klinik bulgunun da eşlik ettiği sistemik bir hastalıktır. Navarro et al. 59 vakalık BEO serilerinde ateş $\% 88$, terleme $\% 73$ ve skrotal ağrı ve yumuşaklık \%100 olduğu (3). Akıncı et al. BEO vakalarının \%

Tablo 1. Olguların klinik bulguları

\begin{tabular}{|c|c|c|c|c|c|c|c|}
\hline Anamnez & Olgu 1 & Olgu 2 & Olgu 3 & Olgu 4 & Olgu 5 & Olgu 6 & Olgu 7 \\
\hline Meslek & İşçi & Emekli & Çiftçi & Kokoreççide çalışıyor & Hayvancılık & Çoban & Memur \\
\hline Hayvanlarında düşük & + & - & + & - & + & + & - \\
\hline $\begin{array}{l}\text { Taze peynir yeme öyküsü } \\
\text { Semptomlar }\end{array}$ & - & + & - & - & - & + & + \\
\hline Ateş & + & + & + & + & + & + & + \\
\hline Myalji & + & + & - & + & - & + & - \\
\hline Artralji & + & + & - & + & - & + & - \\
\hline Gece terlemesi & + & - & + & - & - & + & + \\
\hline Halsizlik & + & + & - & - & - & + & + \\
\hline
\end{tabular}


Tablo 2. Olguların fizik muayene ve laboratuvar bulguları

\begin{tabular}{|c|c|c|c|c|c|c|c|}
\hline Fizik Muayene & Olgu 1 & Olgu 2 & Olgu 3 & Olgu 4 & Olgu 5 & Olgu 6 & Olgu 7 \\
\hline Ateş & - & + & + & + & + & - & + \\
\hline Eklem tutulumu & - & - & - & - & - & - & - \\
\hline Hepatosplenomegali & - & - & - & - & - & - & + \\
\hline Tutulan testis & - & Sağ & Sağ & Sağ & Sol & Sağ & Sağ \\
\hline $\begin{array}{l}\text { Testiste ağrı/şişlik/kızarıklık/ısı artışı } \\
\text { Laboratuvar }\end{array}$ & $+/+/-/-$ & $-/+/+/-$ & $+/+/+1+$ & $-/+/-/-$ & $-/+/+/-$ & $+/+/-/-$ & $+/+/-/-$ \\
\hline Beyaz Küre $(\mu L)$ & 7800 & 7300 & 11500 & 17500 & 7160 & 11890 & 5800 \\
\hline Hemoglobin & 12,9 & 13,2 & 12,9 & 14,6 & & & 13,5 \\
\hline Trombosit sayımı $(\mu L)$ & 252000 & 245000 & 172000 & 213000 & 238000 & 149000 & 200000 \\
\hline $\mathrm{CRP}(\mathrm{mg} / \mathrm{l})$ & 41,1 & 16,1 & 186 & 127 & 1.94 & 17.9 & 14,8 \\
\hline ESR (mm/saat) & 55 & 30 & 65 & 35 & 16 & 32 & 13 \\
\hline AST ( U/I) & 68 & 32 & 70 & 53 & 20 & 25 & 34 \\
\hline ALT ( U/I) & 79 & 55 & 34 & 93 & 16 & 25 & 41 \\
\hline Testis USG & - & + & + & + & + & + & + \\
\hline
\end{tabular}

47,1'inde üriner semptomlar, \% 53'ünde ateş ve artralji, \%24'ünde kilo kaybı gibi BEO dışı semptomlarında eşlik ettiği görülmüştür (13). Bizim hastalarımızda da ateş, myalji, artralji, gece terlemesi, kilo kaybı gibi semptomlarında testis tutulumuna ek olarak görüldüğü saptanmıştır (Tablo-1).

Brusellozda laboratuvar bulgularında non spesifik değişiklikler görülmekte olup; CRP ve eritrosit sedimantasyon hızında artış, AST ve ALT yükselmeleri, anemi, lökopeni, lökositoz ve trombositopeni bruselloz tanısı alan hastalarda görülebilecek değişikliklerdir. Navarro et al. 59 vakalık BEO serisinin \%63'ünde ESR 20 mm/saat üzerinde iken, $\% 35$ 'inde $40 \mathrm{~mm} / \mathrm{saat}$ üzerinde saptanmıştır. Genel olarak çalışmadaki hastalarda CRP yüksekliği, anemi, lökositoz, lökopeni, trombositopeni, karaciğer fonksiyonlarında artma gibi bulgular saptanmıştır (3). Bizim hastalarımızın ikisinde CRP 100 mg/lt ve üzeri iken; ESR iki hastada $30 \mathrm{~mm} / \mathrm{saat}$ altında idi. Lökositoz üç hastamızda mevcutken; üç hastamızda kan kültüründe Brusella spp. üremesi bulunmaktaydı (Tablo-2).

Bruselloz tanısı esas olarak hikaye, klinik bulgular ve Brusella tüp aglütinasyonu veya kan kültüründe üreme ile konulmaktadır (14). Kan kültürünün her yerde yapılamaması, bakterinin kan kültüründe geç ve zor üremesi nedeni ile hastalığın tanısında serolojik testler ön plana çıkmaktadır. Basit ve tarama amaçlı kullanılan Rose bengal testi Navarro et al. 59 vakalık serisinde hastaların tamamında pozitifken; STA testi $\% 52$ 'sinde 160 ve üstü şeklinde sonuçlanmıştır ve hastaların \% 93'ünde ise coombs testinin $1 / 320$ ve üzerinde olduğu görülmüştür (3). Güneş et al. 15 vakalık serilerinde \% 93' nde STA testi pozitifken; $\% 7$ ' sinde coombs testi pozitifliği bulunmaktadır (15). Kliniğimizde takip ettiğimiz yedi hastanın beşinde STA testi pozitif (1/160 ve üzeri) iken; iki hastada STA testi negatif (1/80) saptandı. Negatif gelen iki hastada ise coombs testi yapılarak BEO tanısı konuldu (Tablo-3). $\mathrm{Bu}$ iki olguyu göz önünde tuttuğumuzda; endemik bölgeden epididimoorşit vakalarında STA testi negatif olsa bile; brusellozdan şiddetle şüphelendiğimiz olgularda coombslu tüp aglütinasyon testi, 2-Merkaptoetanol (2 ME), Brucellacapt, ELISA gibi diğer testlerin istenmesi ya da hastanın 2 hafta sonra tekrar değerlendirilmesi uygun olan yaklaşımlardır.

Brucella spp. retiküloendotelyal sistemin fakültatif hücre içi parazitidir. İnkübasyon periyodu 5 gün ila 2 ay arasında değişen bu bakteri; başta kan ve kemik iliği kültürleri olmak üzere çeşitli klinik örneklerin kültürlerinden elde edilebilmektedir. Hastalığın tanısında kültür altın standarttır ve

Tablo 3. Olguların Brusella epididimoorşit tanı bulguları

\begin{tabular}{|c|c|c|c|c|c|c|c|}
\hline Laboratuvar & Olgu 1 & Olgu 2 & Olgu 3 & Olgu 4 & Olgu 5 & Olgu 6 & Olgu 7 \\
\hline Rose bengal & + & + & + & + & + & + & + \\
\hline STA & $1 / 160$ & $1 / 640$ & $1 / 320$ & $1 / 80$ & - & $1 / 640$ & $1 / 1280$ \\
\hline Coombs TA & - & - & - & $1 / 160$ & $1 / 160$ & - & - \\
\hline Kan kültürü & - & + & + & - & + & - & - \\
\hline
\end{tabular}


izolasyon gerçekleştiğinde kesin tanı koydurur. Ancak kültürlerin duyarlılığı, örneğin alındığı evre, kullanılan besiyeri sistemi (otomatik ya da konvansiyonel kan kültürü sistemi vb.), örnek almadan önce antibiyotik başlanmış olup olmadığı gibi çeşitli faktörlerden etkilenmektedir (16). Kültürlerde üretilmesinde birçok faktörden etkilenen bu bakteriye bağlı gelişen brusella epididimoorşitli vakaların incelendiği yayınlarda kan kültürü pozitifliğinin \% 14-69 arasında değiştiği bildirilmiştir (14). 34 merkezin katılımcı olduğu ve 390 genitoüriner brusellozun irdelendiği çok merkezli bir çalışmada kan kültüründe etkenin elde edilmesi \% 36,5 olarak saptanmıştır (9). Kliniğimizde takip ettiğimiz yedi BEO hastasının üçünün kan kültüründe Brucella spp. üremesi olduğu saptanmıştır (Tablo-3).

Brusella tedavisinde kombine ve uzun süreli tedavi uygulanması komplikasyonların gelişiminin önlenmesi için önemlidir. Dünya Sağlık Örgütü bruselloz tedavisi için; doksisiklin 2x100 mg ve rifampisin 1x600 mg 45 gün süre ile ya da doksisiklin 2x100 mg ve 3 hafta süre ile $1 \times 1 \mathrm{~g}$ uygulamasıdır (17). Olgularımızın beşinde rifampisin ve doksisiklin 6 hafta süreyle kullanılırken; sadece bir olguda 14 gün streptomisin ve doksisiklin tedavisinin ardından rifampisin ve doksisiklin ile tedavi 6 haftaya tamamlanmıştır. Verdiğimiz tedavi ile olgularımızın hiçbirinde relaps görülmemiştir.

Sonuç olarak brusellozun endemik olduğu bölgelerde farklı klinik tablolarla karşımıza çıkabileceğini göz önünde bulundurmak gerekmektedir. Geçim kaynağının yaygın olarak hayvancılık olduğu bölgelerde hastalık ve bulaşma yolları hakkında halkın bilgilendirilmesi, bruselloz ve komplikasyonlarının önemli ölçüde azalmasını sağlayacaktır (18).

Çıkar Çatışması: Çalışmada herhangi bir çıkar çatışması yoktur.

Finansal Çıkar Çatışması: Çalışmada herhangi bir finansal çıkar çatışması yoktur.

Yazışma Adresi: Merve Sefa Sayar, TC. SBÜ. Van Eğitim ve Araştırma Hastanesi, Süphan Mahallesi Hava Yolu Kavşağı 1. Kilometre Edremit, Van

e-mail: drmervesefasayar@yahoo.com

Telefon: +90(432) 4449965

Fax: +90(432) 2121954

\section{KAYNAKLAR}

1. Pappas G, Papadimitriou P, Akritidis N, et al. The new global map of human brucellosis. Lancet Infect Dis. 2006;6(2):91-9.

2. Kaya S. Bruselloz ve tedavi sorunu. İnfeksiyon Dergisi (Turkish Journal of Infection) 2006;20(3):227-30.

3. Navarro AM, Solera J, Corredoira J, et al. Epididymoorchitis due to brucella mellitensis: A retrospective study of 59 patients. Clin Infect Dis 2001;33(12):2017-22.

4. Kilic AU, Metan G, Alp E. Clinical presentations and diagnosis of brucellosis. Recent Pat Anti infect Drug Discov 2013;8(1):34-41.

5. Demiroğlu ZY, Turunç T, Alışkan H, et al. Brusellozlu 151 olgunun klinik, laboratuar ve epidemiyolojik özelliklerinin retrospektif değerlendirilmesi. Mikrobiyoloji bülteni 2007; 41:517-27

6. Najafi N, Ghassemian R, Davoody AR, et al. An unusual complication of a common endemic disease: Clinical and laboratory aspects of patients with brucella epididymoorchitis in the north of Iran. BMC Research Notes 2011;4:286.

7. Gözükara K, Görür S. Ürogenital enfeksiyonlar ve erkek infertilitesi. Androloji bülteni 2015;17(60):43-8.

8. Köse A, Akdemir E, Büyüktuna SA. Brucella epididymoorchitis: An evaluation of eight cases. J Turgut Ozal Med Cent 2014:21(4):254-8.

9. Erdem H, Elaldı N, Ak O, et al. Genitourinary brucellosis: Results of a multicentric study. Clinical Microbiology and Infection 2014;20(11):847-53.

10. Ducrotoy MJ, Bertu WJ, Ocholi RA, et al. Brucellosis as an emerging threat in developing economies: Lessons from Nigeria. PLOS Negl Trop Dis 2014;8(7):e3008.

11. Coşkun Ö, Gül HC, Mert G, et al. Brucellar epididymoorchitis: A retrospective study. Trakya Univ Tip Fak Derg 2009;26(3):220-5.

12. Buzgan $\mathrm{T}$, Karahocagil $M K$, Irmak $\mathrm{H}$, et al. Clinical manifestations and complications in 1028 cases of brucellosis: A retrospective evaluation and review of the literature. International Journal of Infectious Diseases 2010;14(6):469-78.

13. Akıncı E, Bodur $H$, Çevik MA, et al. A complication of brucellosis: Epididymoorchitis. Int J Infect Dis 2006;10(2):1717.

14. Ural O, Dikici N. Brucella epididimoorşiti: Beş olgu sunumu. Klimik dergisi 2010;23(1):22-5

15. Güneş M, Geçit I, Bilici S, et al. Brucellar epididymoorchitis: Report of fifteen cases. Van Tıp Dergisi 2010;17(4):131-5.

16. Bulaşıcı Hastalıkların Laboratuvar Tanısı İçin Saha Rehberi. BRUSELLOZ* Ondülan Ateş, Malta Humması, ICD10:A23.0-A23.3.

17. Brucellosis in humans and animals. WHO/CDS/EPR/2006.

18. Uluğ M, Uluğ NC. Brusellozlu 78 olgunun değerlendirilmesi. Klimik Dergisi 2010;23(3):89-94. 